\title{
The Safety of Balinese Traditional Food "Urutan" Made from Chicken Meat Based on Metal Contamination
}

\author{
A.A. Made Semariyani dan I Wayan Sudiarta \\ \{semariyanimega@yahoo.com\}
}

Program Studi Ilmu dan Teknologi Pangan, Fakultas Pertanian, Universitas Warmadewa

\begin{abstract}
Urutan" is a sausage analog food product traditionally made in Bali. To satiate the taste of consumers, market demands and food diversification, the raw material used is no longer from pork alone, but also from chicken meat. The purpose of this study is therefore to determine whether there is metal contamination in the "urutan" made from chickens, in an effort to ensure good quality of the food and safety for consumers. The method used in this study was making a chicken "urutan" with the best formulation from previous studies [1][2], and subsequently testing the chicken "urutan" for the presence of heavy metals like $\mathrm{Pb}, \mathrm{Zn}$, and $\mathrm{Cu}$, using the Atomic Absorbance Spectroscopy method. The results obtained from raw, steamed and fried "urutan" shows the presence of lead $(\mathrm{Pb})$ with value ranging from $0.2167-1.0570 \mathrm{mg} / \mathrm{kg}$, presence of Copper $(\mathrm{Cu})$ with value ranging from $0.0181-0.2718 \mathrm{mg} / \mathrm{kg}$, and presence of Zinc (Zn) with value ranging from $3.3727-7.1724 \mathrm{mg} / \mathrm{kg}$. Therefore, all the values meet the standard requirements for meat sausage (SNI 01-3820-1995).
\end{abstract}

Keywords : “urutan”, food safety, metal contamination

\section{Pendahuluan}

'Urutan' merupakan produk pangan analog sosis yang dibuat secara tradisional di Bali melalui proses fermentasi maupun tanpa fermentasi. Pembuatan 'urutan' biasanya dilakukan pada saat hari raya Galungan, dimana masyarakat memotong babi untuk keperluan upacara, sehingga daging yang tersedia cukup banyak. Masyarakat berupaya memperpanjang masa simpan daging tersebut dengan mengolahnya menjadi produk pangan yang dapat disimpan lebih lama. Ada dua cara yang umum dilakukan oleh masyarakat Bali, yaitu dengan mengeringkan menjadi dendeng dan dengan difermentasi menjadi 'urutan', 'bebontot', 'brengkes', 'buntilan' dan 'takilan celeng' [3][4][5].Secara umum 'urutan' terbuat dari daging dan lemak babi, garam dan rempah-rempah (Merica, cabe merah, ketumbar, jahe dan kencur) dengan atau tanpa penambahan gula, menggunakan selongsong usus babi, dijemur di bawah sinar matahari selama tiga sampai lima hari, kemudian disimpan pada suhu ruang, sehingga terjadi proses fermentasi secara alamiah [6]. Namun saat ini "urutan" sudah dibuat secara 
komersial dan diperdagangkan baik di pasar tradisional maupun pasar modern. Untuk memenuhi selera konsumen, tuntutan pasar dan penganekaragaman pangan, bahan baku yang digunakan tidak lagi dari daging babi saja, tetapi sekarang sudah ada di pasaran "urutan" yang dibuat dari daging ayam, "urutan" ini terutama diperuntukan bagi konsumen yang tidak mengkonsumsi daging babi atau yang alergi terhadap daging babi, serta selongsong atau casing yang digunakan berupa selongsong sintesis yang dapat dimakan (edible film).

Sebagai makanan tradisional yang masih sangat digemari oleh masyarakat Bali dan sudah mulai diminati wisatawan dalam dan luar negeri, kualitas dan keamanan "urutan" ayam belum banyak diketahui. Untuk itu perlu dilakukan penelitian untuk mencari formulasi yang tepat agar diperoleh "urutan" ayam dengan karakteristik yang baik, aman, serta disukai oleh konsumen. Sehingga masyarakat yang ingin menjadikan 'urutan' ayam sebagai oleh-oleh, yakin bahwa 'urutan' ayam aman dikonsumsi serta memiliki kualitas yang terjamin. Hasil penelitian diharapkan dapat memberi informasi mengenai formulasi yang tepat, kandungan gizi dan keamanan pangan tradisional 'urutan' ayam dalam upaya meningkatkan kualitas "urutan" ayam dan keamanan pangan tradisional.

\section{Metode Penelitian}

\subsection{Tempat dan Waktu Penelitian}

Penelitian dilaksanakan di Laboratorium Pengolahan Fakultas Pertanian, Universitas Warmadewa Denpasar. Pengujian sampel dan pengamatan dilaksanakan di Laboratorium Fakultas Teknologi Pertanian Universitas Udayana. Waktu penelitian dimulai dari bulan Mei sampai bulan September 2019.

\subsection{Metodologi Penelitian}

Tahap awal dilakukan proses pembuatan "urutan" ayam dengan perlakuan terbaik dari penelitian sebelumnya yaitu penambahan lemak $10 \%$ tanpa perlakuan fermentasi. Setelah itu dilanjutkan dengan pengujian ada tidaknya cemaran logam antara lain Uji Timbal (Pb), Tembaga ( $\mathrm{Cu}$ ), dan Seng (Zn), dengan metode Atomic Absorption Spectroscopy (AAS) [5].

\subsection{Bahan dan Alat}

Bahan-bahan yang digunakan dalam penelitian ini adalah sampel "urutan" ayam dari hasil terbaik dari penelitian sebelumnya yaitu penambahan lemak $10 \%$ tanpa fermentasi, alkohol $70 \%$, aquades, larutan standar $\mathrm{Pb}, \mathrm{Cu}, \mathrm{Zn}$. Alat-alat yang digunakan dalam penelitian ini adalah oven microwave MARS 5, oven, wadah, Teflon, labu ukur $25 \mathrm{ml}$, labu ukur $100 \mathrm{ml}$, test tube $50 \mathrm{ml}$, cawan porselen, botol plastik polystyrene,homogenizer (sentrifuse), timbangan analitik, AAS merk Shimadzu AA7000, Pipet ukur, Mortal, Pastel, Gelas kimia $300 \mathrm{ml}$, botol semprot, plastik steril, labu Erlenmeyer $100 \mathrm{ml}$, cawan petri, lemari asam, neraca analitik, Hotplate, sarung tangan, Masker, Batang pengaduk, computer, Atomic Absorption Spectroscopy (AAS), kertas saring whatman, Aquabides, dan asam nitrat HNO3.

\subsection{Tahap Pelaksanaan}

Kegiatan pada tahap pelaksanaan adalah sebagai berikut :

1. Membuat "'urutan" ayam dengan perlakuan $10 \%$ lemak tanpa proses fermentasi 
2. Melakukan pengujian atau uji logam berat $(\mathrm{Pb}, \mathrm{Cu}$, dan $\mathrm{Zn})$ terhadap daging ayam,"urutan" ayam mentah, "urutan" ayam yang telah dikukus dan "urutan" ayam yang telah digoreng dengan menggunakan metode Atomic Absorption Spectroscopy (AAS).

\section{Hasil Dan Luaran Yang Dicapai}

\subsection{Hasil Penelitian}

Pengamatan terhadap logam berat indikator keamanan pangan untuk "urutan"ayam yang diamati sesuai dengan standar mutu menurut SNI 01-3820-1995 yaitu meliputi uji logam berat Timbal $(\mathrm{Pb})$, Tembaga $(\mathrm{Cu})$ dan Seng $(\mathrm{Zn})$. Pengamatan logam berat dilakukan secara menyeluruh antara lain terhadap bahan baku daging ayam yang digunakan, urutan ayam mentah, urutan ayam yang dikukus, dan urutan ayam yang telah digoreng. Hasil pengamatan terhadap logam berat yang terdapat dalam "urutan" ayam dan daging ayam yang digunakan sebagai bahan baku dapat dilihat pada Tabel 5.1. Hasil yang diperoleh dari uji logam berat terhadap "urutan" ayam yaitu kandungan Timbal $(\mathrm{Pb})$ memenuhi standar yang dipersyaratkan baik "urutan" mentah, dikukus, maupun yang digoreng nilainya berkisar antara 0,2167 sampai $1,0570 \mathrm{mg} / \mathrm{kg}$. Terjadi penurunan kadar timbal $(\mathrm{Pb})$ akibat proses pengolahan. Daging ayam mentah kadar timbalnya berkisar antara $1,0078-1,0570 \mathrm{mg} / \mathrm{kg}$ setelah diolah menjadi "urutan" (mentah) terjadi penurunan kadar timbal $(\mathrm{Pb})$ menjadi 0,5789 - $0,5815 \mathrm{mg} / \mathrm{kg}$. "Urutan” ayam mentah setelah dilakukan proses pengukusan mengalami penurunan kadar timbal $(\mathrm{Pb})$ dari $0,5789-0,5815 \mathrm{mg} / \mathrm{kg}$ menjadi $0,2167-0,2345 \mathrm{mg} / \mathrm{kg}$ sedangkan "urutan" ayam setelah dilakukan proses penggorengan mengalami penurunan kadar timbal $(\mathrm{Pb})$ menjadi $0,4267-0,4351 \mathrm{mg} / \mathrm{kg}$. Terjadinya penurunan kadar timbal $(\mathrm{Pb})$ akibat proses pengolahan kemungkinan disebabkan oleh proses penguraian atau degradasi $\mathrm{Pb}$ akibat proses pemanasan pada pengukusan dan penggorengan. Proses pengukusan menurunkan kadar $\mathrm{Pb}$ lebih tinggi dari pada penggorengan hal ini disebabkan karena pada pengukusan menggunakan uap air panas pada panci tertutup sehingga timbal yang ada pada "urutan" terbawa oleh uap air panas dan jatuh dalam panci pengukus [8] yang menyatakan bahwa proses perebusan dapat mengurangi logam berat $\mathrm{Pb}$ pada daging ikan kupang.

Tabel 1. Kadar Logam Berat Daging Ayam Mentah, “Urutan”Ayam Mentah, "Urutan” Ayam yang Dikukus dan "Urutan" Ayam yang Digoreng $(\mathrm{mg} / \mathrm{kg})$

\begin{tabular}{ccccc}
\hline No & $\begin{array}{c}\text { Kode } \\
\text { Sampel }\end{array}$ & $\begin{array}{c}\text { Kadar Logam } \\
\mathrm{Pb}(\mathrm{mg} / \mathrm{kg})\end{array}$ & $\begin{array}{c}\text { Kadar Logam } \\
\mathrm{Cu}(\mathrm{mg} / \mathrm{kg})\end{array}$ & $\begin{array}{c}\text { Kadar Logam Zn } \\
(\mathrm{mg} / \mathrm{kg})\end{array}$ \\
\hline 1 & $\mathrm{U} 1 \mathrm{M}$ & 0,5815 & 0,0181 & 3,3727 \\
2 & $\mathrm{U} 2 \mathrm{M}$ & 0,5789 & 0,0183 & 3,8585 \\
3 & $\mathrm{U} 1 \mathrm{G}$ & 0,4351 & 0,2482 & 5,6091 \\
4 & $\mathrm{U} 2 \mathrm{G}$ & 0,4267 & 0,2718 & 4,5496 \\
5 & $\mathrm{U} 1 \mathrm{~K}$ & 0,2345 & 0,1750 & 3,4191 \\
6 & $\mathrm{U} 2 \mathrm{~K}$ & 0,2167 & 0,1763 & 5,1037
\end{tabular}




$\begin{array}{lllll}7 & \text { DM1 } & 1,0570 & 0,1098 & 6,1037 \\ 8 & \text { DM2 } & 1,0078 & 0,0959 & 7,1724\end{array}$

Sumber : Hasil uji di Unit Laboratorium Fakultas Teknologi Pertanian Universitas Udayana, 2019

Keterangan Tabel :

$$
\begin{aligned}
& \mathrm{U1M}=\text { Urutan Ayam Mentah Ulangan I } \\
& \mathrm{U} 2 \mathrm{M}=\text { Urutan Ayam Mentah Ulangan II } \\
& \mathrm{U1G}=\text { Urutan Ayam Goreng Ulangan I } \\
& \mathrm{U} 2 \mathrm{G}=\text { Urutan Ayam Goreng Ulangan II } \\
& \mathrm{U1K}=\text { Urutan Ayam Kukus Ulangan I } \\
& \mathrm{U} 2 \mathrm{~K}=\text { Urutan Ayam Kukus Ulangan II } \\
& \mathrm{DM} 1=\text { Daging Ayam Mentah Ulangan I } \\
& \mathrm{DM} 2=\text { Daging Ayam Mentah Ulangan II }
\end{aligned}
$$

Kandungan Tembaga $(\mathrm{Cu})$ pada daging mentah, "urutan" mentah, "urutan" yang dikukus dan "urutan" yang digoreng berkisar antara 0,1098 sampai 0,1098 mg/kg. Daging ayam mentah kadar tembaganya berkisar antara $0,0959-0,1098 \mathrm{mg} / \mathrm{kg}$ setelah diolah menjadi urutan (mentah) terjadi penurunan kadar tembaga $(\mathrm{Cu})$ menjadi $0,0181-0,0183 \mathrm{mg} / \mathrm{kg}$. "Urutan" ayam mentah setelah dilakukan proses pengukusan mengalami peningkatan kadar tembaga $(\mathrm{Cu})$ dari 0,0181 - 0,0183 $\mathrm{mg} / \mathrm{kg}$ menjadi $0,1750-0,1763 \mathrm{mg} / \mathrm{kg}$ sedangkan "urutan" ayam setelah dilakukan proses penggorengan mengalami peningkatan kadar tembaga $(\mathrm{Cu})$ menjadi $0,2482-0,2718 \mathrm{mg} / \mathrm{kg}$. Terjadinya peningkatan kadar tembaga $(\mathrm{Cu})$ akibat proses pengolahan kemungkinan disebabkan oleh proporsi $\mathrm{Cu}$ meningkat karena akibat proses pemanasan pada pengukusan dan penggorengan menyebabkan berkurangnya kadar air sehingga secara proporsional kadar timbal $(\mathrm{Cu})$ meningkat.

Kandungan Seng (Zn) pada daging mentah, "urutan" mentah, "urutan” ayam yang dikukus dan "urutan" ayam yang digoreng berkisar antara 3,3727 sampai $7.1724 \mathrm{mg} / \mathrm{kg}$ Terjadi penurunan kadar Seng ( $\mathrm{Zn}$ ) akibat proses pengolahan. Daging ayam mentah kadar Sengnya berkisar antara 6,1037 - 7,1724 mg/kg setelah diolah menjadi "urutan" (mentah) terjadi penurunan kadar Seng (Zn) menjadi 3,3727 - 3,8585 mg/kg. "Urutan" ayam mentah setelah dilakukan proses pengukusan mengalami peningkatan kadar Zeng (Zn) dari 3,3727 - 3,8585 ppm menjadi 3,4191 - 5,1037 mg/kg sedangkan "urutan" ayam setelah dilakukan proses penggorengan mengalami peningkatan kadar Seng (Zn) menjadi 4,5496 - 5,6091 mg/kg. Terjadinya penurunan kadar Seng (Zn) akibat proses pengolahan kemungkinan disebabkan oleh proses penguraian atau degradasi $\mathrm{Zn}$ akibat proses pemanasan pada pengukusan dan penggorengan. Proses pengukusan menurunkan kadar Zn lebih tinggi dari pada penggorengan hal ini disebabkan karena pada pengukusan menggunakan uap air panas pada panci tertutup sehingga $\mathrm{Zn}$ yang ada pada urutan terbawa oleh uap air panas dan jatuh dalam panci pengukus [9] yang menyatakan bahwa proses perebusan dapat menurunkan logam berat Zn pada bahan. Kandungan $\mathrm{Pb}, \mathrm{Cu}$ dan $\mathrm{Zn}$ daging ayam, "urutan" ayam mentah, "urutan” ayam yang dikukus dan "urutan" ayam yang digoreng memenuhi persyaratan standar sosis daging [7] yang mana 
persyaratan $\mathrm{Pb}$ adalah maksimal 2,0 mg/kg, $\mathrm{Cu}$ adalah maksimal $20 \mathrm{mg} / \mathrm{kg}$ sedangkan $\mathrm{Zn}$ maksimal $40 \mathrm{mg} / \mathrm{kg}$. Sehingga "urutan" ayam yang dibuat dengan formula penambahan lemak 10\% tanpa difermentasi aman untuk dikonsumsi.

\subsection{Luaran Yang Dicapai}

Luaran dari penelitian ini antara lain adalah produk "urutan" ayam dengan karakteristik yang baik, laporan penelitian, artikel untuk seminar nasional dan dimuat dalam jurnal Sustainable Environment Agricultural Science (SEAS), serta Teknologi Tepat Guna (TTG) pembuatan "urutan" ayam dengan karakteristik yang baik, aman (bebas dari cemaran mikroba dan cemaran logam) serta disukai oleh konsumen.

\section{Kesimpulan}

Hasil yang diperoleh dari uji logam berat terhadap daging ayam mentah, "urutan" ayam mentah, "urutan" ayam yang dikukus dan digoreng memenuhi persyaratan standar sosis daging (SNI 01-3820-1995) yang mana persyaratan kadar Timbal (Pb) adalah maksimal 2,0 $\mathrm{mg} / \mathrm{kg}$, Tembaga $(\mathrm{Cu})$ adalah maksimal $20 \mathrm{mg} / \mathrm{kg}$, dan Seng (Zn) maksimal $40 \mathrm{mg} / \mathrm{kg}$ sedangkan hasil uji terhadap sampel semuanya berada di bawah batas maksimal tersebut (kadar Pb berkisar antara 0,2167 - 1,0570 mg/kg, kadar $\mathrm{Cu}$ berkisar antara 0,0181 - 0,2718 $\mathrm{mg} / \mathrm{kg}$ dan kadar Zn berkisar antara 3,3727 - 7,1724 mg/kg). Maka berdasarkan SNI 013820-1995 tentang sosis daging dapat disimpulkan bahwa "urutan" ayam yang dibuat dengan formula penambahan lemak $10 \%$ tanpa proses fermentasi aman untuk dikonsumsi.

\section{References}

[1]. Semariyani, A.A. M, I Wayan Sudiarta dan Luh Suriati. 2017. Cita Rasa Pangan Tradisional "Urutan" Khas Bali Berbasis Daging Ayam. Fakultas Pertanian, Universitas Warmadewa, Denpasar, Bali

[2]. Semariyani, A.A. M dan I Wayan Sudiarta. 2018. Keamanan Pangan Tradisional "Urutan" Khas Bali Berbasis Daging Ayam Ditinjau Dari Cemaran Mikroba. Fakultas Pertanian, Universitas Warmadewa, Denpasar, Bali

[3]. Antara, N.S., I.N. Sujaya, A.Yokota, K. Asano, W.R. Aryanta, and F. Tomita. 2002. Identification and Succession of Lactic Acid Bacteria During Fermentation of 'urutan', a Balinese Indigenous Fermented Sausage. Word J. of Microbiology \& Biotechnology 18: 255262.

[4]. Partama, I W.S., N. S. Antara, dan L.P. Wrasiati. 2005. Pengaruh Penambahan Bawang Puth dan Lama Fermentasi Terhadap Mutu Mikrobiologis Dan Organoleptik Bebontot. Seminar 
Nasional Pengembangan Teknologi Pertanian Berbasis Penggunaan (User Based Oriented), 13 September 2005. Universitas Udayana. Denpasar

[5]. Nocianitri, K.A. 2009. Urutan. Pusat Kajian Makanan Tradisional. Universitas Udayana. Denpasar.

[6]. Aryanta, W.R. 2000. Utilization of Lactic Acid Bacteria to Improve the Quality of Balinese Traditional Fermented Sausage. Characteristics of Balinese Traditional Fermented Sausage. International Center of Biotechnology Osaka University. Osaka. Japan. P. 610 - 616

[7]. Badan Standarisasi Nasional .1995. Standar Nasional Indonesia (SNI) 01-3820-2015 Tentang sosis Daging. Jakarta

[8]. Candra, Dewi Diana. 2012. Determinasi Kadar Logam Timbal (PB) Dalam Makanan Kaleng Menggunakan Dekstruksi Basah dan Dekstruksi Kering. Alchemy. Vol 2 No 1

[9]. Putri,Tirta Edriana Erlita. 2017. Analisis Kandungan Tembaga (Cu) dalam Sosis Ayam dan Sosis Sapi Secara Spektrofotometer Serapan Atom 